\title{
WHAT'S \\ HAPPENING \\ IN \\ Without Borders
}

\section{From the Editor}

\section{Gretchen Birbeck, MD, MPH}

Back in July, Neurology ${ }^{\circledR}$ published an interesting article on lessons from on outreach clinic in Peru providing "multidisciplinary neurologic care to a population with a substantial burden of disease in an area with very few but some neurologic expertise. The impetus for developing the program described by Vishnevetsky and colleagues was the very high burden of Huntington disease (HD) in the area around the Cañete valley about 3 hours outside of Lima. HD occurs at rates $\sim 4$ times expected. Through 2 days of clinic and community-based outreach provided every 3 months, they are able to bring specialty care and critical home-based assessments to not only the HD population but the broader group of people in area with chronic neurologic disorders."

I was interested in learning more about the program and the authors were kind enough to answer my questions. This in-print interview can be found in the Global Stuff You Should Know section of Without Borders. Two of the authors answer questions on media interactions, noting that "Using journalism and the media in a deliberate, thoughtful way (not all media is good media in this case) is important," as well as giving the reader insights on the administration of the program, and how they were able to build trust and ongoing relationships in the community.

\section{Reference}

1. Vishnevetsky A, Illanes-Manrique M, Inca-Martinez M, et al. Neurology outreach clinic for Huntington disease in Peru: lessons for neurodegenerative diseases. Neurology Epub 2018 July 6.

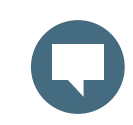

\section{Blog}

Read the Without Borders blog for timely posts by the editor and invited guests.

NPub.org/wbblog 


\section{Neurology}

\section{What's happening in Without Borders \\ Neurology 2018;91;507 \\ DOI 10.1212/WNL.0000000000006187}

This information is current as of September 10, 2018

\section{Updated Information \&} Services

Permissions \& Licensing

\section{Reprints}

including high resolution figures, can be found at: http://n.neurology.org/content/91/11/507.full

Information about reproducing this article in parts (figures,tables) or in its entirety can be found online at:

http://www.neurology.org/about/about_the_journal\#permissions

Information about ordering reprints can be found online:

http://n.neurology.org/subscribers/advertise

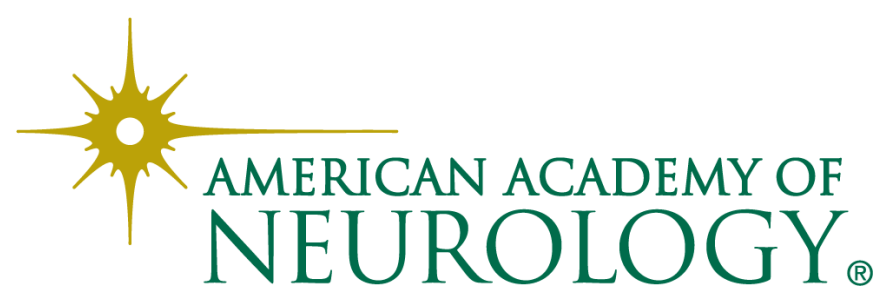

